\title{
The effects of tricyclazole treatment on aquatic macroinvertebrates in the field and in laboratory
}

\author{
B. Rossaro, P. Cortesi \\ Department of Food, Environmental and Nutritional Sciences, University of Milan, Italy
}

\begin{abstract}
The effects of tricyclazole treatments on benthic macroinvertebrates in the field and in laboratory were studied. In field conditions, low density of benthic populations was observed, both in treated and untreated plots, which was attributed to the short period of submersion of the rice field and high water temperature, fungicide treatments had no significant effect. Both laboratory acute toxicity test and a test using a mesocosm suggested a low toxicity of tricyclazole on invertebrates. A reduction of the macroinvertebrate density was observed only when tricyclazole concentration was applied at concentrations 100 times the ones tested in the field, acute toxicity test gave an $\mathrm{LC}_{50}$ after $48 \mathrm{~h}$ of 26 $\mathrm{mg}^{*} \mathrm{~L}^{-1}$, in agreement with data obtained for other species.
\end{abstract}

\section{Introduction}

Rice paddy fields, as man modified ecosystems derived from natural wetlands (Odum \& Barret, 2005), are characterized by periodic floods and droughts and become an habitat suitable for some aquatic invertebrates.

Correspondence: Bruno Rossaro, Department of Food, Environmental and Nutritional Sciences, University of Milan, via Celoria 2, 20133 Milan, Italy. Tel.+ +39.02.5031.6734 - Fax: +39.02 .5031 .6748 .

E-mail: bruno.rossaro@unimi.it

Key words: rice field, fungicide, benthic macroinvertebrates, tricyclazole, ecotoxicology, bioassay.

Acknowledgements: research supported in part by Dow Agrosciences Italia S.r.l.

Received for publication: 24 June 2013.

Revision received: 22 August 2013.

Accepted for publication: 24 September 2013.

(C) Copyright B. Rossaro and P. Cortesi, 2013

Licensee PAGEPress, Italy

Journal of Entomological and Acarological Research 2013; 45:e23

doi:10.4081/jear.2013.e23

This article is distributed under the terms of the Creative Commons Attribution Noncommercial License (by-nc 3.0) which permits any noncommercial use, distribution, and reproduction in any medium, provided the original author(s) and source are credited.
Macroinvertebrates give a significant contribution to the ecosystem biodiversity and are a common component of rice field fauna (Leitão et al., 2007). However, the species diversity in this human modified system and its reduction in relation to water management, addition of fertilizers and pesticides treatments has been poorly investigated.

Natural ecosystems evolve toward an increase in diversity accompanied by a decrease in production (Odum \& Barret, 2005). This is exactly the opposite of agriculture ecosystems, where the aim is to enhance productivity with a consequent decrease in biodiversity. The management of water inflow and outflow has a huge effect on benthic macroinvertebrates, since many species cannot tolerate temporary absence of soil submersion, as well as herbicide, insecticide and fungicide treatments could cause density reduction or selective elimination of some sensitive species (Stener et al., 2009).

In Italy, among chemicals employed in rice paddy fields, tricyclazole is widely used to manage rice blast epidemics, caused by the fungus Magnaporthe oryzae (Bertocchi et al., 2007; Cortesi, 2011). At present the main effects of tricyclazole on rice blast are relatively well known (Kunova et al., 2013), whereas the information about its side effects on benthic macroinvertebrates in rice fields is scarce, and only few studies focused on the impact of tricyclazole on aquatic macroinvertebrates (Simpson \& Rogert, 1991; Faria et al., 2007; Suarez-Serrano et al., 2010; Hayasaka et al., 2012; Rossaro et al., 2013; Tsochatzis et al., 2013). Little information about tricyclazole acute toxicity is also available (Encarna et al., 2009; Tsochatzis et al., 2013). The application of a fungicide could interfere with aquatic macroinvertebrate metabolism, for example with chitin synthesis (Grigarick et al., 1990), or it could alter biological interactions between different components of the community (competitors, predators). The aim of the present research was to assess acute toxicity of tricyclazole on Chironomus riparius and to compare the effect of tricyclazole in a mesocosm and in a rice field treated with different concentrations of tricyclazole.

\section{Material and methods}

The rice paddy field, where the study was carried out, is located at Poiago farm in Carpiano (Milan, Italy). The experimental design consisted of 5 plots, each of $42 \mathrm{~m}^{2}$, inside a field with continuous water supply (Figure 1A). Each plot was delimited by soil dykes and had independent inlet water supply and no outlet to avoid cross contamination. Plots were sown in dry soil, with Oryza sativa subsp. japonica cv Sirio, and the crop was submerged at 3 leaf-tillering phenological stage. Fungicide treatments were randomly assigned to plots. Tricyclazole was applied as commonly used to manage rice blast epidemics, i.e. two treatments at $300 \mathrm{~g}^{*} \mathrm{ha}^{-1}$ of the commercial fungicide Beam DAS WP (Lilly Research Lab., Eli Lilly and Co., Indianapolis, IN, USA) (tricyclazole $75 \%$ ) and as single treatments at 600 and $1200 \mathrm{~g}^{*} \mathrm{ha}^{-1}$ (Table 1). 
Fungicide aqueous solutions were sprayed on the crop at $500 \mathrm{~L}^{*} \mathrm{ha}^{-1}$ with the motorised backpack sprayer Fox F320 with a hand-held $1.5 \mathrm{~m}$ boom, operating at $500 \mathrm{Kpa}$.

In 2011, benthic macroinvertebrates were sampled with a cylindrical core sampler, $7 \mathrm{~cm}$ in diameter. Four random replicate samples were collected within each plot. Plots 1 and 5 were used as controls and were sampled at 6 dates; two controls allow estimation of the variability between plots, not bound to treatment. Treatments were applied to plots 2-3-4; sampling was done immediately before the fungicide treatment and the sampling in each treated plot continued weekly for 2 weeks in plot 3 and 4 , while in plot 2 two treatments were applied on the $14^{\text {th }}$ of July and on the $4^{\text {th }}$ of August, and sampling continued for 5 weeks after the first treatment so that it finished 2 weeks after the second treatment (Table 1).

In 2012, the second year of study, the core sampler was replaced by a square hand net; $30 \mathrm{~cm}$ of size, with a net mesh of 300 micron, the net

A

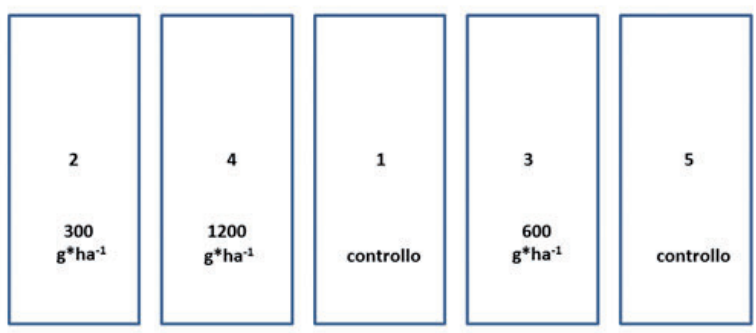

B

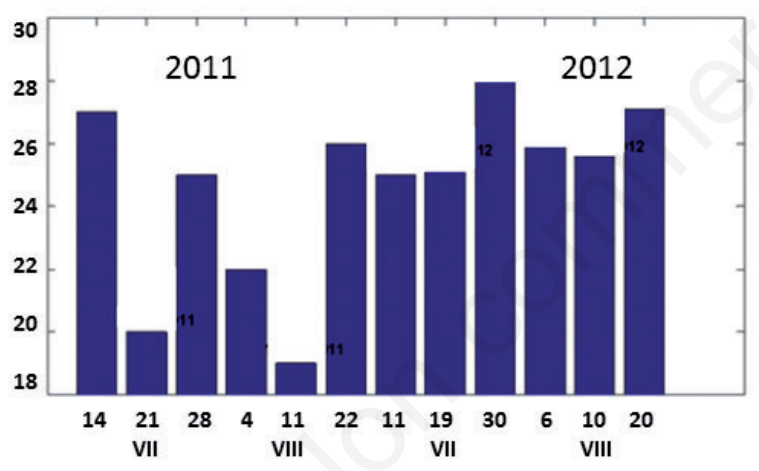

Figure 1. A) spatial disposition of treatment plots, B) water temperature in the investigated periods. was drawn over the submerged soil, making a low pressure. This sampling technique is not as quantitative as the core sampler, but collects macroinvertebrates on a larger surface, allowing the capture of a larger numbers of specimens.

Because of the two different sampling tools, a comparison between the two years is biased, however, transformation of counts to in $\mathrm{m}^{-2}$ allowed a rough comparison between years. For each species, the number of specimens found in each sample was counted.

The counts in the core sampler were then multiplied by, having the core $7 \mathrm{~cm}$ of diameter, whereas the counts of the samples collected with the hand net were multiplied by 3.33 , assuming that $1 / 3$ of square meter surface was sampled.

A total of 134 samples were studied: 104 samples in 2011: 4 replicates $* 3$ plots $* 2$ dates +4 replicates $* 5$ plots $* 4$ dates, and 30 samples in 2012: 5 plots at 6 sampling dates. The two untreated plots allowed an estimation of the variance not bound to treatment.

In both years, samples were collected early in the morning, and immediately after brought to the laboratory. At the same day the samples were separated into different fractions with sieves of 10000, 1000, 500 and 300 micron mesh size. Benthic macroinvertebrates obtained from each fraction were separated from detritus with the aid of a stereomicroscope, transferred into Eppendorf tubes and fixed in alcohol $75^{\circ}$ or in formol 4\% (oligochaetes). Because of the low numbers of specimens found, the whole sample was always examined without subsampling. The specimens were counted under the stereomicroscope at $30 \mathrm{X}$ magnification and identified to species level using different identification keys (Campaioli et al., 1994, 1999; Timm, 2009; Wiederholm, 1983); the species identification often required the preparation of permanent slides examined with the aid of an optical microscope at high magnification (1000 X).

Water temperature $\left({ }^{\circ} \mathrm{C}\right)$ was measured in the field with a digital thermometer at sampling. Water samples were collected in acidcleaned graduated bottles for chemical analysis by standard methods (APHA, 2005). The following analyses were performed in laboratory on the same day or the day after: dissolved oxygen $\left(\mathrm{mg} \mathrm{L}^{-1}\right)$ determined with Winkler method, conductivity $\left(\mu \mathrm{Scm}^{-1}\right), \mathrm{pH}$, alkalinity $\left(\mathrm{mg} \mathrm{L}^{-1}\right.$ of $\mathrm{CaCO}_{3}$ ) measured by titrating with $\mathrm{HCl}$ until color change of methyl red, bromocresol green, total phosphorous (TP) concentration was measured with the phosphomolybdic method.

Two tanks with a capacity of $20 \mathrm{~L}$ were used for the mesocosm test. The sediment for the mesocosm test was obtained adding about $2 \mathrm{~kg}$ (dry weight) of soil, collected from the Carpiano rice field.

The two tanks were prepared on 8/5/2012; one was used as control, the other for the experiment, where an aqueous suspension of tricyclazole was added on two dates, 8/5/2012 and 15/5/2012. The quantities added were $0.266 \mathrm{~g}$ of Beam DAS at 8/5/2012 and $1.333 \mathrm{~g}$ at 15/5/2012, corresponding to 0.2 and $1 \mathrm{~g}$ of tricyclazole, to have a concentration in

Table 1. Dates of treatment.

\begin{tabular}{|c|c|c|}
\hline $14 / 7 / 2011$ & $1^{\circ}$ sampling & $1^{\circ}$ treatment on plot 2 \\
\hline 21/7/2011 & $2^{\circ}$ sampling & $3^{\circ}$ sampling \\
\hline $4 / 8 / 2011$ & $4^{\circ}$ sampling & $2^{\circ}$ treatment on plot $2,1^{\circ}$ treatment on plots 3,4 \\
\hline $11 / 8 / 2011$ & $5^{\circ}$ sampling & $6^{\circ}$ sampling \\
\hline 11/7/2012 & $1^{\circ}$ sampling & $1^{\circ}$ treatment on plot 2 \\
\hline 19/7/2012 & $2^{\circ}$ sampling & $3^{\circ}$ sampling \\
\hline \multicolumn{2}{|c|}{$2^{\circ}$ treatment on plot 2} & $1^{\circ}$ treatment on plots 3,4 \\
\hline 6/8/2012 & $4^{\circ}$ sampling & $5^{\circ}$ sampling \\
\hline $20 / 8 / 2012$ & $6^{\circ}$ sampling & \\
\hline
\end{tabular}


the water of 10 and $50 \mathrm{mg}^{*} \mathrm{~L}^{-1}$ respectively, estimated as 100 and 500 $\mathrm{mg}^{*} \mathrm{~kg}^{-1}$ in the sediment. A sample of about 100 larvae of Chironomus riparius coming from a rearing in our (DeFENS) department was added on 8/5/2012 in each tank. In the same rearing two oligochaetes (Dero digitata and Limnodrilus hoffmeisteri), one copepod (Mesocyclops leuckarti) and one cladocera (Moina brachiata) were present. $C$. riparius larvae at the third and fourth instar were counted at the beginning of the experiment, after 7 and 14 days on 15/5 and 22/5/2012.

Tricyclazole concentration present in the soil of the rice field and in the mesocosm was measured by Neotron spa using the method Icms-Qpos-A and the analytical technique LC MS/MS. Tricyclazole residue was measured in the five plots investigated (Figure 1A); samples were collected with the same hand net used to sample macroinvertebrates on 6/8/2012, a week after the first treatment (30/7/2012); the tricyclazole concentration in the mesocosm test was measured in a sample collected in the treated tank on 14/6/2012, about one month after the second tricyclazole addition.

\section{Data analysis}

Environmental data and species counts were summarized with Microsoft EXCEL and ACCESS and analyzed using Matlab R2012b® and R 2.15.2® software.

At first, a Shannon diversity index was calculated according to the formula:

$$
H_{i}=\sum_{j=1}^{p}\left(\frac{y_{i j}}{\sum_{j=1}^{p} y_{i_{j}}} * \log _{2} \frac{y_{i j}}{\sum_{j=1}^{p} y_{i_{j}}}\right)
$$

where $y_{i j}$ is the abundance of species $\mathrm{j}$ in the sampling unit (a plot in a sampling date) $i, p$ is the number of species present in the unit $i$ and $\mathrm{H}_{\mathrm{i}}$ is the Shannon diversity index.

Using the Shannon index as dependent variable, a factorial ANOVA was carried out with sampling dates (between years and among weeks within the same year) and tricyclazole treatments as factors. Tricyclazole treatments were coded as: i) 1 no treatment; ii) 2 two treatment with $300 \mathrm{~g}^{*} \mathrm{ha}^{-1} ; 3$ one treatment with $600 \mathrm{~g}^{*} \mathrm{ha}^{-1} ; 4$ one treatment with $1200 \mathrm{~g}^{*} \mathrm{ha}^{-1}$.

Correlations between environmental variables, species abundances and the diversity index were calculated.

Multivariate analysis of variance and covariance (MANCOVA) was carried out using species matrix as dependent variable, tricyclazole concentration and sampling date as target variable and environmental data matrix as covariate matrix (water temperature, $\mathrm{pH}$, dissolved oxygen, conductivity, alcalinity). Species counts were $\log _{10}(y+1)$ transformed before analysis. For each of the three target variables separated MANCOVA were carried out. MANCOVA allows extracting information from each species. Uni- and multivariate F tests were carried out to detect the significance of responses, the multivariate test considered the highest eigenvalue of the matrix product between the inverse of sum of squares (SSQ) within groups (W) with the SSQ between groups (B): $\mathrm{W}^{-1 *} \mathrm{~B}$ (Morrison, 1967).

A canonical correlation analysis was carried out to have a graphical joint representation of the relation between species, environmental variables and plots with different tricyclazole treatments. The analysis searches for linear combination of the environmental set that maximizes the correlation with a linear combination of species.

An acute toxicity test was carried out at the following tricyclazole concentrations: $0,25,50,100 \mathrm{mg} \mathrm{L}^{-1}$. The $\mathrm{LC}_{50}$ was calculated considering mortality at $24,48,72 \mathrm{~h}$. The acute toxicity test was repeated in four dates $(6 / 3 / 2012,19 / 3 / 2012,7 / 5 / 2012,22 / 5 / 2012)$. The parameters of the logistic curve (Ritz et al., 2006) were calculated with tricyclazole con- centration as independent variable and survival fraction as dependent variable. A four-parameter curve was fitted, according to the following equation:

$$
y=f(x,(b, c, d, e))=c+\frac{d-c}{1+\left(\frac{x}{e}\right)^{b}}
$$

which can be expressed in a logarithmic form:

$$
y=f(x,(b, c, d, e))=c+\frac{d-c}{\left(1+\exp \left(b^{*}(\log (x)-\log (e))\right)\right.}
$$

where:

$\mathrm{x}=$ tricyclazole concentration in $\mathrm{mg}^{*} \mathrm{I}^{-1}$;

$\mathrm{y}=\%$ of survival after $48 \mathrm{~h}$;

$\mathrm{d}=$ upper survival limit;

$\mathrm{c}=$ lower survival limit;

$\mathrm{e}=\mathrm{EC}_{50}\left(\mathrm{LC}_{50}\right.$ in the present case);

$\mathrm{b}=$ slope of the curve around the point of inflection.

\section{Results}

Several different invertebrate species were found in the soil of rice field (Table 2). In 2012, 24 taxa were identified, with a higher number of specimens in respect to 2011, when only 13 taxa were collected and in lower number.

The differences in species number and in specimen abundances were probably bound to the different sampling tool used in the two years, but the different water temperature pattern measured in the two years should also be taken into account (Figure 1B). The presence of high numbers of Polypedilum nubifer in 2012 and its absence in 2011 is of special interest (Figure 2A). On the opposite, Branchyura sowerbyi was more abundant in 2011 (Figure 2B): this is also a thermophilous species abundant in rice fields; a competition between these two species may be an explanation of the observed results.

The different sampling technique must be in any case considered when these results are discussed.

The tricyclazole concentration in the sediments was measured on the $6^{\text {th }}$ August 2012, with the following results: i) Plot $1<0.2 \mathrm{~g}^{*} \mathrm{~kg}^{-1}$; ii) Plot 2 0.5+/-0.2 $\mathrm{g}^{*} \mathrm{~kg}^{-1}$; iii) Plot $30.9+/-0.2 \mathrm{~g}^{*} \mathrm{~kg}^{-1}$; iv) Plot $41.4+/-0.3$ $\mathrm{g}^{*} \mathrm{~kg}^{-1}$; v) Plot $5<0.2 \mathrm{~g}^{*} \mathrm{~kg}^{-1}$.

The ratio between the tricyclazole concentration in the treatment (performed at 30/7/2012) and its concentration in the soil a week after (6/8/2012) was calculated (Table 3$)$.

For the calculation following considerations were taken: the sediment was sampled with a hand net over a surface of about $1 / 3 \mathrm{~m}^{2}$, sediment was collected until a depth of about $2 \mathrm{~cm}$, the soil density was about 2.5 $\mathrm{kg} \mathrm{m}^{-3}$. With these assumptions $16.665=2.5^{*} 1000^{*} 0.02 * 0.3333 \mathrm{~g}$ of substrate should have been sampled. If these assumptions are true it could be concluded that after a week, tricyclazole amount remaining in the soil varies from $1 / 3$ to $1 / 5$ of the tricyclazole sprayed. The approximate calculation is:

conc in treatm $\left[\mathrm{mg}^{*} \mathrm{~m}^{-2}\right]$

(conc in soil $\left[\mathrm{mg} \mathrm{kg}^{-1}\right] *$ soil density $\left[\mathrm{kg}^{*} \mathrm{~m}^{-3}\right] *$ soil depth $[\mathrm{m}] *$ surface sampled $\left[\mathrm{m}^{2}\right]$

Shannon diversity index (mean values) in the control and in the treated plots (Figure 2C) confirmed that no substantial differences were observed in relation to tricyclazole treatment. Factorial ANOVA with Shannon diversity as dependent variable and tricyclazole concentrations, years and weeks as factors, emphasized highly significant differences between years and among weeks, whereas no significant difference was found in correlation to tricyclazole treatment (Table 4), 
Table 2. The species found.

\begin{tabular}{|c|c|c|c|c|c|}
\hline Class & Order & Family & Taxon & \multicolumn{2}{|c|}{ Year } \\
\hline Oligochaetes & & Naididae & Dero digitata & 2011 & 2012 \\
\hline & & Tubificidae & $\begin{array}{l}\text { Branchyura sowerbyi } \\
\text { Limnodrilus hoffmeisteri } \\
\text { Oligochaetes cocoon }\end{array}$ & $\begin{array}{l}2011 \\
2011\end{array}$ & $\begin{array}{l}2012 \\
2012 \\
2012\end{array}$ \\
\hline Hirudinea & & Glossiphoniidae & Glossiphonia heteroclita & 2011 & 2012 \\
\hline Gasteropoda & $\begin{array}{c}\text { Pulmonata } \\
\text { Prosobranchia }\end{array}$ & $\begin{array}{l}\text { Planorbidae } \\
\text { Physidae }\end{array}$ & $\begin{array}{l}\text { Gyralus albus } \\
\text { Physa fontinalis }\end{array}$ & $\begin{array}{l}2011 \\
2011\end{array}$ & $\begin{array}{l}2012 \\
2012\end{array}$ \\
\hline Ostracoda & & & & 2011 & 2012 \\
\hline Copepoda & & Cyclopidae & Mesocyclops leuckarti & 2011 & 2012 \\
\hline Cladocera & Cladocera & Daphniidae & Moina brachiata & 2011 & 2012 \\
\hline Hemiptera & & Notonectidae & Notonecta glauca & & 2012 \\
\hline Neuroptera & & Chrysopidae & Chrysopa sp. & & 2012 \\
\hline Coleoptera & & $\begin{array}{c}\text { Gyrinidae } \\
\text { Dityscidae } \\
\text { Hydrophilidae } \\
\text { Elmintidae } \\
\text { Hydrochidae }\end{array}$ & $\begin{array}{l}\text { Dityscus marginalis } \\
\text { Hydrophilus piceus } \\
\text { Elmis maugetii }\end{array}$ & 2011 & $\begin{array}{l}2012 \\
2012 \\
2012 \\
2012 \\
2012\end{array}$ \\
\hline Diptera & & $\begin{array}{c}\text { Culicidae } \\
\text { Ceratopogonidae } \\
\text { Stratiomyidae } \\
\text { Tabanidae } \\
\text { Chironomidae }\end{array}$ & $\begin{array}{c}\text { Ochlerotatus caspius } \\
\text { Tabanus sp. } \\
\text { Tanypus punctipennis } \\
\text { Polypedilum nubeculosum } \\
\text { Tanytarsus fimbriatus } \\
\text { Polypedilum nubifer } \\
\text { Chironomus annularius }\end{array}$ & $\begin{array}{l}2011 \\
2011\end{array}$ & $\begin{array}{l}2012 \\
2012 \\
2012 \\
2012\end{array}$ \\
\hline
\end{tabular}

A

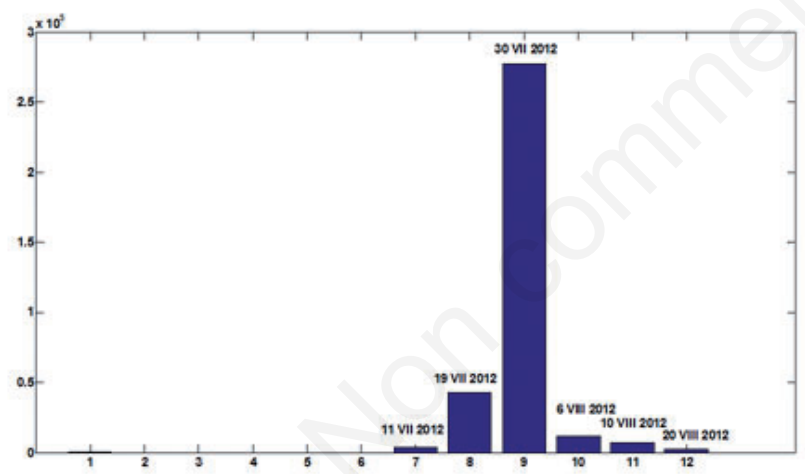

C

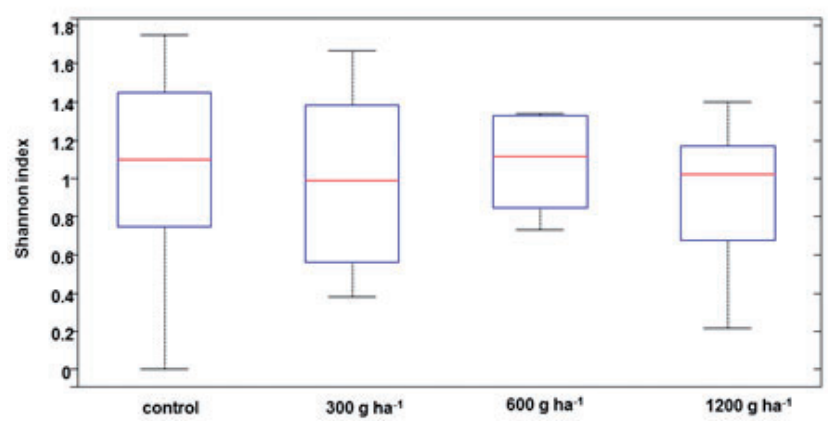

B

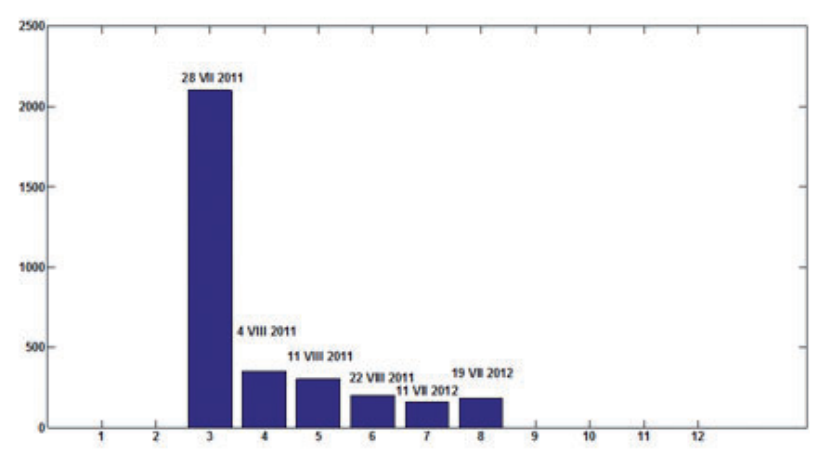

D

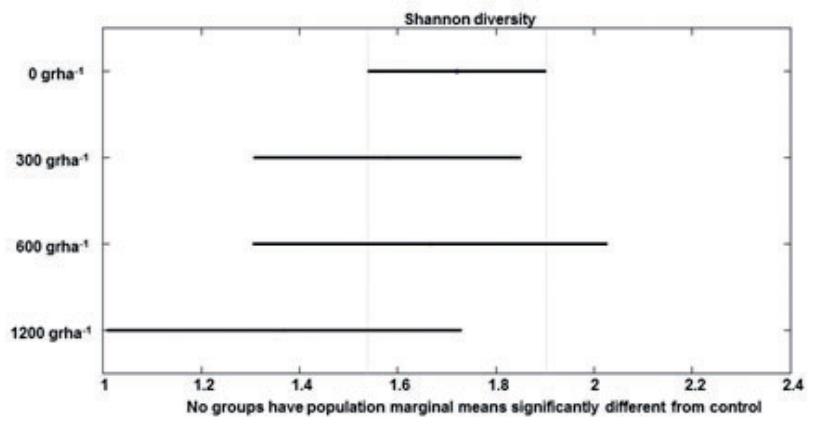

Figure 2. A) P. nubifer $\left(\right.$ ind $^{*} \mathrm{~m}^{-2}$ ) during the sampled period, B) B. sowerbyi (ind $\mathrm{m}^{-2}$ ) during the sampled period, C) Shannon diversity index at different tricyclazole concentrations (median values and $25 \%$ and $75 \%$ percentiles, D) Bonferroni multiple comparisons. 
this was confirmed by a Bonferroni multiple comparison test which never gave significant differences between pairs (Figure 2D).

A multivariate analysis of variance and covariance (MANCOVA) allowed a more detailed analysis of obtained results. The species matrix with 21 species in 56 samples (26 in 2011 and 30 in 2012) was included as the dependent variables matrix, the matrix of environmental variables in the same 56 samples with water temperature, dissolved oxygen, $\mathrm{pH}$, conductivity, and alkalinity, was treated as a covariate matrix, the target variables were treatment, the two years and a temporal trend, coded as an integer from 1 to 6 indicating the first and the $6^{\text {th }}$ sampling week respectively; separate analyses were carried out for each target variable. MANOVA without covariates and MANOVA using the environmental variables as target were also carried out (Table 5).

A univariate $\mathrm{F}$ test was performed to analyze the contribution of each species to sum of squares (Table 6).

The multivariate test did not show any significant difference bound to treatment, but highlighted differences between years and among weeks.

In the univariate tests, few species showed significant differences, but the species counts were not linearly decreasing with tricyclazole concentrations, therefore obtained results must be interpreted with caution.

Table 3. Ratio between tricyclazole concentration in the treated plots (performed at 30/7/2012) and its concentration in the soil a week after (6/8/2012).

\begin{tabular}{lcc} 
Concentration in treatment $(\mathrm{t})$ & Concentration in soil (c) Ratio t/c \\
$0 \mathrm{~g}^{*} \mathrm{ha}^{-1}=0 \mathrm{mg}^{*} \mathrm{~m}^{-2}$ & $<0.2 \mathrm{~g}^{*} \mathrm{~kg}^{-1}$ & 0.0 \\
$300 \mathrm{~g} \mathrm{ha}^{-1}=30 \mathrm{mg}^{*} \mathrm{~m}^{-2}$ & $0.5 \mathrm{~g}^{*} \mathrm{~kg}^{-1}$ & 3.6 \\
\hline $600 \mathrm{~g}^{*} \mathrm{ha}^{-1}=60 \mathrm{mg}^{*} \mathrm{~m}^{-2}$ & $0.9 \mathrm{~g}^{*} \mathrm{~kg}^{-1}$ & 4.0 \\
$1200 \mathrm{~g}^{*} \mathrm{ha}^{-1}=120 \mathrm{mg}^{*} \mathrm{~m}^{-2}$ & $1.4 \mathrm{~g}^{*} \mathrm{~kg}^{-1}$ & 5.2 \\
\hline
\end{tabular}

Table 4. Factorial ANOVA results, with Shannon diversity as dependent variable, tricyclazole, years and weeks as factors.

\begin{tabular}{lccccc} 
Source & Sum Sq. & d.f. & Mean Sq. & F & Prob>F \\
Among treatment & 0.6955 & 3 & 0.2318 & 1.1444 & - \\
Error & 10.5350 & 52 & 0.2026 & - & - \\
Total & 11.2305 & 55 & - & 1.1742 & 0.3399 \\
Treatment & 0.6002 & 3 & 0.2001 & 10.8338 & - \\
Between years & 1.8458 & 1 & 1.8458 & - & $0.0018^{* *}$ \\
Error & 8.6892 & 51 & 0.1704 & 1.1044 & - \\
Total & 11.2305 & 55 & - & 7.2159 & - \\
Treatment & 0.2900 & 3 & 0.0967 & - & 0.3583 \\
Among weeks & 6.9468 & 11 & 0.0315 & - \\
Error & 3.5882 & 55.0000 & - & - \\
Total & 11.2305 & & & - \\
\hline
\end{tabular}

S.q., ; d.f., ; Prob, probabilities. ${ }^{* * P}<0.01$.

Table 5. Multivariate analysis of variance and covariance.

\begin{tabular}{|c|c|c|c|}
\hline Target variable & $\begin{array}{l}\text { Target variables corrected } \\
\text { for covariates } \\
\text { (MANCOVA) }\end{array}$ & $\begin{array}{l}\text { Target variables not corrected } \\
\text { for covariates } \\
\text { (MANOVA) }\end{array}$ & $\begin{array}{l}\text { Environmental } \\
\text { variables alone }\end{array}$ \\
\hline \multicolumn{4}{|l|}{ F test } \\
\hline Treatment & 0.8175 & 2.5438 & 17.4968 \\
\hline Year & 5.7726 & 21.6395 & 27.1358 \\
\hline Trend & 16.4429 & 26.7760 & 24.5270 \\
\hline \multicolumn{4}{|l|}{ Prob di F } \\
\hline Treatment & 0.6986 & 0.0109 & 0.0000 \\
\hline Year & $0.0000^{* *}$ & 0.0000 & 0.0000 \\
\hline Trend & $0.0000^{* *}$ & 0.0000 & 0.0000 \\
\hline \multicolumn{4}{|c|}{ Eigenvalue of $\mathrm{W}^{-1} * \mathrm{~B}$} \\
\hline Treatment & 0.788 & 1.908 & 9.998 \\
\hline Year & 5.566 & 16.230 & 15.506 \\
\hline Trend & 15.856 & 20.082 & 14.015 \\
\hline
\end{tabular}

Prob, probabilities. ${ }^{*} \mathrm{P}<0.05 ; * * \mathrm{P}<0.01$. 
The two species giving significantly different response to treatment showed a clear drop in density only at concentrations increasing from 600 to 1200 , well above the ones normally applied (Table 7).

The sum of squares bound to treatment was much lower than the SSQ due to years and to weeks (Figure 3, Table 5). The error SSQ was very high respect to all the other sources of SSQ, the SSQ trace of error sum of squares ranged from 947 to 1102 , while the trace of the SSQ due to tricyclazole treatment was 51.38, the one due to years was 207, the trace of SSQ due to weeks was 91, a large trace of SSQ was bound to covariates (temperature, conductivity, alkalinity, pH, TP) and was equal to 777.

The canonical correlation analysis summarized the response of the community to environmental variables; it was evident that $\mathrm{pH}$, conductivity and alcalinity were the most important contributors to the observed SSQ along the first canonical axis, while water temperature, dissolved oxygen and total phosphorous contributed more to SSQ in the second axis, the tricyclazole treatment was not able to order plots according to increasing tricyclazole concentration applied (Figure 4).

\section{Acute toxicity test}

Results of the acute toxicity test are summarized in Table 8 and Figure 5. Survival at $48 \mathrm{~h}$ was used to calculate the $\mathrm{LC}_{50}$. The fitted loglogistic curve with four parameters gave an estimated value of the tricyclazole $\mathrm{LC}_{50}=26 \mathrm{mg}^{*} \mathrm{~L}^{-1}$, with a standard error of $3 \mathrm{mg}^{*} \mathrm{~L}^{-1}$.

\section{Mesocosm test}

Population dynamics of Chironomus riparius in a mesocosm was analyzed in the presence of other species, the oligochaetes Dero digitata and Limnodrilus hoffmeisteri and the cladocera Mesocyclops and Moina brachiata in a tank treated with tricyclazole (see Materials and methods section).

On 14/6/2012 the content of tricyclazole in sediment was analyzed on $11 / 6 / 29012$, giving a value of $96 \mathrm{mg} \mathrm{kg}^{-1}$. It can be concluded that $0.192=96 /(100+500)$ or approximately $16 \%$ of the tricyclazole added in the water could be found in the sediment one month after.

A decrease in number of the larvae in the fourth stage of development was observed with increasing tricyclazole treatment. The larvae in the third stage showed an increase in number one week after the first treatment (15/5/2012), while on 22/5/2012 (week after the second

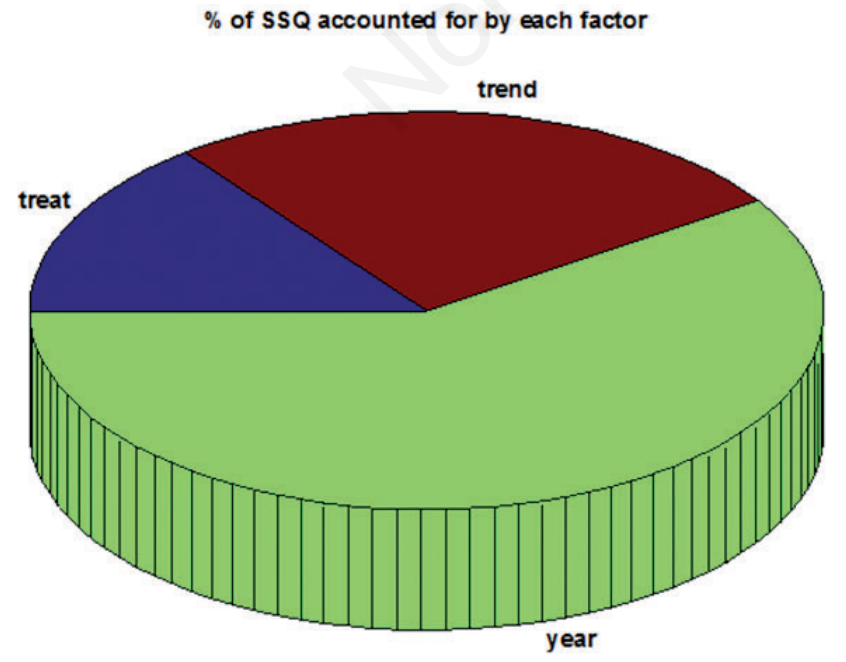

Figure 3. Proportion of sum of square (SSQ) due to different treatments; treat=SSQ bound to tricyclazole concentration, trend=SSQ bound to differences among weeks (temporal trend), year=SSQ bound to differences between years.
Table 6. Univariate $F$ test, with treatment as target and environmental variables (water temperature, oxygen, conductivity and alcalinity as covariates.

\begin{tabular}{lll} 
Treatment & F & Prob \\
P. nubifer & 7.267 & $0.010^{* *}$ \\
D. marginalis & 6.730 & $0.013^{*}$ \\
\hline N. glauca & 4.938 & $0.031^{*}$ \\
Ceratopogonidae & 4.916 & $0.031^{*}$ \\
\hline T. fimbriatus & 4.723 & $0.035^{*}$ \\
Stratiomyidae & 4.154 & $0.047^{*}$ \\
\hline Hydrochidae & 1.628 & 0.208 \\
Chrysopa sp. & 1.399 & 0.243 \\
\hline Chironomus annularius & 1.316 & 0.257 \\
Oligochaetes cocoon & 0.980 & 0.327 \\
\hline Ostracoda & 0.577 & 0.451 \\
P. fontinalis & 0.460 & 0.501 \\
\hline O. caspius & 0.428 & 0.516 \\
E. maugetii & 0.207 & 0.651 \\
\hline G. albus & 0.096 & 0.758 \\
Tabanus sp. & 0.054 & 0.817 \\
\hline B. sowerbyi & 0.029 & 0.866 \\
Oligochaetes imm & 0.028 & 0.867 \\
\hline H. piceus & 0.023 & 0.879 \\
G. heteroclita & 0.004 & 0.951 \\
\hline Pob,prat & &
\end{tabular}

Prob, probabilities. ${ }^{*} \mathrm{P}<0.05 ;{ }^{* *} \mathrm{P}<0.01$.

Table 7. Densities of two species at different treatments.

\begin{tabular}{lcc}
$\log _{10}\left(\right.$ ind $\left./ \mathrm{m}^{2}+1\right)$ & P. nubifer & D. marginalis \\
Control & 2.300 & 1.96 \\
$300 \mathrm{~g} \mathrm{ha}^{-1}$ & 1.77 & 1.33 \\
\hline $600 \mathrm{~g}^{*} \mathrm{ha}^{-1}$ & 2.02 & 1.05 \\
$1200 \mathrm{~g}^{*} \mathrm{ha}^{-1}$ & 0 & 0.45 \\
\hline
\end{tabular}

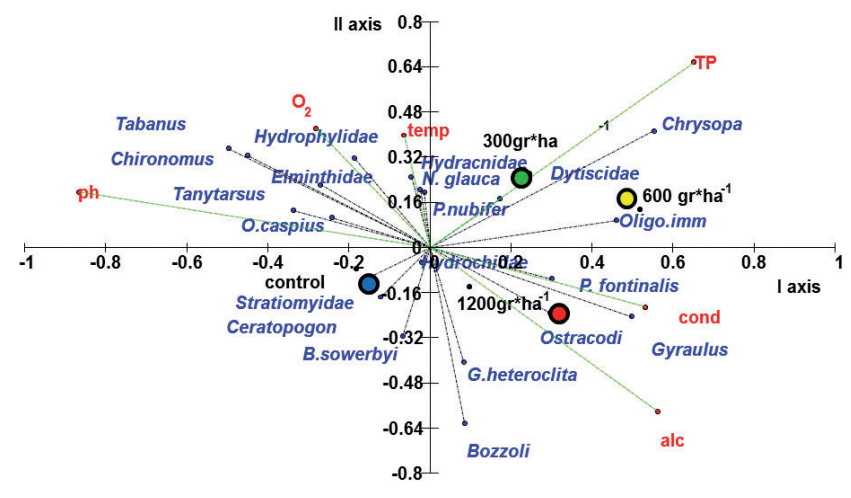

Figure 4. Canonical correlation analysis; species and environmental variables scores in the plot of the first two axes. A circle of different color maps the stations grouped according to tricyclazole treatment. 
treatment with the highest tricyclazole concentration, performed on $15 / 5 / 2012,50 \mathrm{mg} \mathrm{L}^{-1}=500 \mathrm{mg} \mathrm{kg}^{-1}$ ), evidenced a drop in numbers (Figure 6). It must be emphasized that in this experiment benthic macroinvertebrates were in contact with tricyclazole concentrations much higher (500 $\mathrm{mg} \mathrm{kg}^{-1}$ ) than the highest one measured in the field, which was equal to $1.4 \mathrm{mg} \mathrm{kg}^{-1}$ at most.

\section{Conclusions}

The field and mesocosm experiments carried out in 2012, together with acute toxicity tests allowed a better description of tricyclazole effects on benthic macroinvertebrates, outlined in the field investigation carried out in 2011 (Rossaro et al., 2012), in which period of soil submersion and temperature fluctuations were considered the most relevant confounding effects in detecting the influence of the fungicide on benthic macroinvertebrates. For this reason field study in 2012 was accompanied by laboratory and mesocosm tests.

In 2011, only 4 species were collected in significant numbers, in particular 2 snails: Gyraulus albus and Physa fontinalis, 1 oligochaetes: Branchyura sowerbyi and 1 leech: Glossiphonia heteroclita. Gyraulus albus, the most common species, rarely reached densities near to 10,000 ind $\mathrm{m}^{-2}$, while oligochaetes, probably all belonging to Branchyura sowerbyi, rarely were estimated with densities above 1000 ind $\mathrm{m}^{-2}$.

The short time of soil submersion (two months between rice field inundation and the first sampling date) did not probably allow the transformation of the mineral compact terrestrial soil in a soft substrate suitable to benthic macroinvertebrates colonization. This condition led us to modify the sampling technique in 2012 . The hand net was preferred to core sampler, allowing sampling only the superficial substrate, richer in fauna, on a larger area. In this manner a qualitative research of the most represented species was preferred to a strictly quantitative sampling. The result was a larger number of species captured (24), compared to 13 species sampled in 2011.

During 2011, beside snails, few Coleoptera, two chironomid species Tanypus punctipennis and Polypedilum nubeculosum, and the mosquito Ochlerotatus caspius were sampled.

In 2012 the hand net allowed to sample many species of aquatic insects, Hemiptera and Coleoptera above all, chironomids were also collected in larger numbers with more species. The presence and abundance of $P$. nubifer in 2012, not captured in 2011, was the most striking result. This is an Afrotropical species, strictly termophilous, which invaded other continents including Europe and America and is characteristically abundant in rice fields. $P$. nubifer tolerates water temperatures around $30^{\circ} \mathrm{C}$. The lower water temperature in 2011 may be a reason of its absence in this year. On the other hand, the higher Hemiptera and Coleoptera numbers captured in 2012 were probably related to sampling technique.

No statistical analysis was able to detect any effect of tricyclazole treatment on fauna composition, while large differences were observed between the two years and among weeks.

This conclusion was supported by a factorial ANOVA followed by Bonferroni multiple comparison, which was unable to emphasize an effect of tricyclazole on Shannon diversity, whereas both seasonal and between-year-difference were significant.

Multivariate analysis of variance and covariance and canonical correlation analysis again emphasized the importance of seasonal succession bound to variation in water temperature and conductivity and the negligible influence of fungicide treatment on benthic invertebrates.

Tricyclazole was found to be degraded in water $\left(\mathrm{DT}_{50}=16.4\right.$ days $)$ but persistent in soil ( $\left(\mathrm{DT}_{50}=197\right.$ days) (Tsochatzis et al., 2013); our results do not allow to estimate the persistence of tricyclazole in soil, even if suggested at least in the mesocosm a shorter degradation time, near-

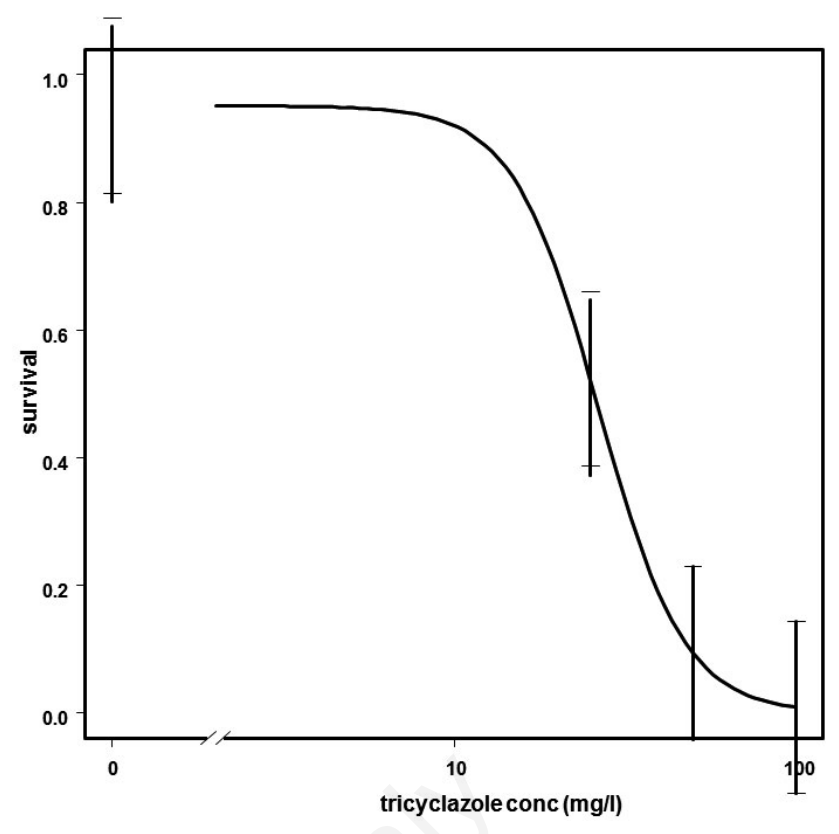

Figure 5. Acute toxicity test: survival of Chironomus riparius at different tricyclazole concentrations after $48 \mathrm{~h}$ treatment; 4 parameters log-logistic curve.
C.rip III

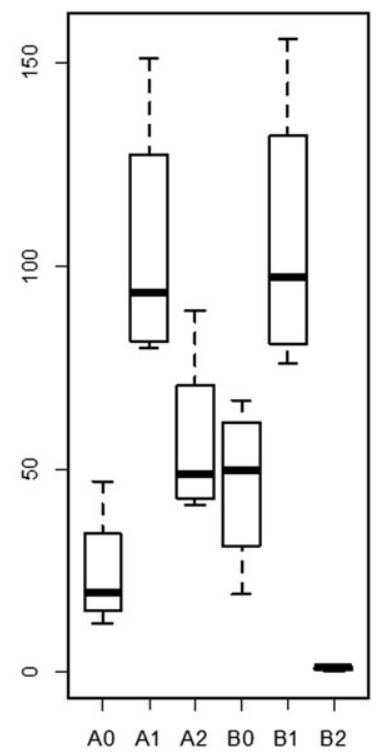

C.rip IV

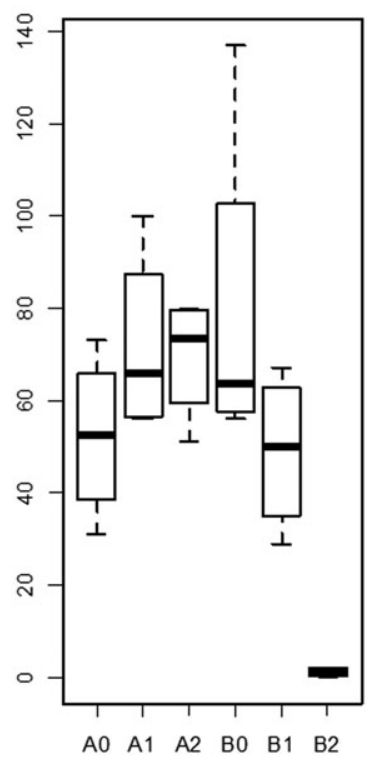

Figure 6. Counts of Chironomus riparius larvae at III and IV instar a week after the application of different concentrations of tricyclazole. A0: untreated tank at the beginning of the experiment (no treatment), A1: untreated tank a week after the application of $100 \mathrm{mg} \mathrm{L}^{-1}$ of tricyclazole in tank B, A2: untreated tank a week after the application of $500 \mathrm{~m} \mathrm{gL}^{-1}$ in $\operatorname{tank} \mathrm{B}, \mathrm{BO}$ treated tank at the beginning of the experiment (no treatment), B1: a week after the application of $100 \mathrm{mg} \mathrm{L}^{-1}$ of tricyclazole, B2: a week after the application of $500 \mathrm{mg} \mathrm{L}^{-1}$ of tricyclazole. 
Table 8. Acute toxicity test with $C$. riparius, log-logistic model with 4 parameters.

\begin{tabular}{|c|c|c|c|c|c|}
\hline & Parameter & Estimate & Std. error & t-value & P-value \\
\hline Slope: (Intercept) & B & 3.480 & 1.772 & 1.964 & 0.053 \\
\hline Lower limit: (Intercept) & $\mathrm{C}$ & 0.001 & 0.086 & 0.012 & 0.991 \\
\hline Upper limit: (Intercept) & $\mathrm{D}$ & 0.952 & 0.069 & 13.798 & 0.000 \\
\hline $\mathrm{ED}_{50}$ : (Intercept) & E & 26.510 & 2.980 & 8.895 & 0.000 \\
\hline Residual standard error & - & 0.316 & (80 d.f.) & - & - \\
\hline
\end{tabular}

Table 9. Acute toxicity and no effect concentration of 75\% WP, tricyclazole (http://www.dowagro.com ; http://sitem.herts.ac.uk/aeru/footprint/it/ Reports/660.htm ; http://www.pesticideinfo.org/List_AquireAll.jsp?Rec_Id=PC35823).

$\begin{array}{lcccccc}\text { Common name } & \text { Effect } & \text { Time } & \text { LC }_{50} & \text { Min } & \text { Max } & \text { Concentration } \\ \text { units }\end{array}$

er to the one measured in the water by Tsochatzis et al. (2013).

Despite its possible persistence tricyclazole does not seem to have a detrimental effect on benthic macroinvertebrates. Laboratory acute toxicity tests and mesocosm experiments emphasized that the effect can be detected only at concentrations much higher (10-100 times) than the ones measured in the field following treatment. In the mesocosm only concentrations well above $100 \mathrm{mg} \mathrm{kg}^{-1}$ showed an effect on fauna composition, in the field much lower concentrations $(1.4 \mathrm{mg}$ $\mathrm{kg}^{-1}$ ) were measured following the tricyclazole treatment applied at the highest concentrations. The acute toxicity tests carried out with a laboratory population of $C$. riparius gave an $\mathrm{LC}_{50}$ near $26 \mathrm{mgl}^{-1}$ after 48 hours; this value is in agreement with EPA data, EPA data give an $\mathrm{LC}_{50}$ after $3 \mathrm{~h}$ for Daphnia magna equal to $94 \mathrm{mg} \mathrm{L}^{-1}$, or $34 \mathrm{mg} \mathrm{L}^{-1}$ after $48 \mathrm{~h}$ and an $\mathrm{LC}_{50}$ after $48 \mathrm{~h}$ for Ciprinus carpio equal to $22 \mathrm{mg} \mathrm{L}^{-1}$ (Table 9).

The field, mesocosm and laboratory results confirm that the tricyclazole has a low toxicity to benthic macroinvertebrates; therefore it is possible to conclude that there is no concern about its application in nature at the concentrations recommended for control of fungal infection. The matter merits a deeper study in any case. One question is if different benthic macroinvertebrate taxa can express different tolerance to tricyclazole in relation to their particular metabolic pathways. In particular it was recently demonstrated the ability of Chironomids to perform melanin synthesis, giving higher tolerance to toxic metals (Loayza-Muro et al., 2013), it is of particular interest in considering the interference of tricyclazole with melanin synthesis (Kunova et al., 2013), this requires further study but can be a basis to explain a tolerance of some benthic macroinvertebrates to tricyclazole toxicity.

\section{References}

APHA (American Public Health Association), 2005 - Standard methods for the examination of water and wastewater, $21^{\text {th }}$ ed. - American Public Health Association, American Water Works Association, and Water Environment Federation, Washington, DC.
BERTOCCHI D., PIZZATTI C., CORTESI P., 2007 - Epidemics and disease management of rice brown spot and rice blast in Italy. In: BOCCHI S., FERRERO A., PORRO A. (eds.), Proc. 4th Temperate Rice Conference, 25-28 June 2007, Novara, Italy: 344-345.

CAMPAIOLI S., GHETTI P. F., MINELLI A., RUFFO S., 1994 - Manuale per il riconoscimento dei macroinvertebrati delle acque dolci italiane. Vol. I. - Provincia Autonoma di Trento: 1-357.

CAMPAIOLI S., GHETTI P. F., MINELLI A., RUFFO S., 1999 - Manuale per il riconoscimento dei macroinvertebrati delle acque dolci italiane. Vol. II. - Provincia Autonoma di Trento: 358.484.

CORTESI P., 2011. - Il brusone del riso: danni causati dalle epidemie e ottimizzazione della difesa con triciclazolo. In: Il ruolo economico del triciclazolo nella risicoltura italiana. - A.G.R.A. srl, Roma: 87-140.

ENCARNA S., FERNÁNDEZ-VEGA C., VILLARROEL M. J., ANDREUMOLINER E., FERRANDO M. D., 2009 - Physiological effects of tricyclazole on zebrafish (Danio rerio) and post-exposure recovery. Comparat. Biochem. Physiol. Part C 2009: 25-32.

FARIA M.S., NOGUEIRA A.J.A., SOARES A.M.V.M., 2007 - The use of Chironomus riparius larvae to assess effects of pesticides from rice fields in adjacent freshwater ecosystems. - Ecotoxicol. Environ. Saf. 67: 218-226.

GRIGARICK A.A., WEBSTER R.K., MEYER R.P., ZALOM F.G., SMITH K.A., 1990. - Effects of pesticide treatments on non-target organisms in California rice paddies. - Hilgardia 58: l-36.

HAYASAKA D., KORENAGA T., SÁNCHEZ-BAYO F., GOKA K., 2012 Differences in ecological impacts of systemic insecticides with different physicochemical properties on biocenosis of experimental paddy fields. - Ecotoxicology 2012: 191-201.

KUNOVA A., PIZZATTI C., CORTESI P, 2013 - Impact of tricyclazole and azoxystrobin on growth, sporulation and secondary infection of the rice blast fungus, Magnaporthe oryzae. - Pest Manage. Sci. 69: 278-284.

LEITÃO S., PINTO P., PEREIRA T., BRITO M. F., 2007 - Spatial and temporal variability of macroinvertebrate communities in two farmed Mediterranean rice fields. - Aquat. Ecol. 41: 373-386.

LOAYZA-MURO R.A., MARTICORENA-RUIZ J.K., PALOMINO E.J., 
MERRITT C., DE BAAT M.L., VAN GEMERT M., et al., 2013 Persistence of Chironomids in metal polluted andean high altitude streams: does melanin play a role? - Environ. Sci. Technol. 47: 601-607.

MORRISON DF., 1967 - Multivariate statistical methods. - McGraw-Hill Co., New York: 343.

ODUM E., BARRET, G.W. 2005 - Fundamental of ecology. - Thomson Brook/Cole, Trad. Ital.: Piccin ed., Padova: 594.

RITZ C., CEDERGREEN N., JENSEN J.E., STREIBIG J.C., 2006 - Relative potency in non similar dose-response curves. - Weed Sci. 54: 407-412.

ROSSARO B., MARZIALI L., CORTESI P., 2013 - The effects of tricyclazole treatment on aquatic invertebrates in a rice paddy field. Clean Soil Air Water [Epub Ahead of Print].

SIMPSON I.C., ROGER P.A., 1991 - The impact of pesticides on nontarget aquatic invertebrates in wetland ricefield. A review. In: PRABHU PINGALI L., PIERRA ROGER A. (eds.), Impact of pesticides on farmer health and the rice environment. - Kluweer Academic Publ., AA Dordrecht, the Netherlands: 249-270.
STENERT C., BACCA R.C., MALTCHIK L., ROCHA 0., 2009 - Can hydrologic management practices of rice fields contribute to macroinvertebrate conservation in southern Brazil wetlands? - Hydrobiologia 635: 339-350.

SUAREZ-SERRANO A., IBANEZ C., LACORTE S., BARATA C. 2010 Ecotoxicological effects of rice field waters on selected planktonic species: comparison between conventional and organic farming. Ecotoxicology 19: 1523-1535.

TIMM T., 2009 - A guide to the freshwater Oligochaeta and Polychaeta of Northern and Central Europe. - Lauterbornia 66: 1-235.

TSOCHATZIS E. D., TZIMOU-TSITOURIDOU R., MENKISSOGLUSPIROUDI U., 2013 - Laboratory and field dissipation of penoxsulam, tricyclazole and profoxydim in rice paddy systems. Chemosphere 91: 1049-1057.

WIEDERHOLM T., 1983 - Chironomidae of the Holoarctic region. Keys and diagnoses. Part. 1. Larvae. - Entomol. Scand. Suppl. 19:1-457. 